\title{
CCR5 32 POLYMORPHISM NOT DETECTED IN HIV PATIENTS IN VOLUNTARY COUNSELING AND TESTING MOEWARDI GENERAL HOSPITAL SURAKARTA, INDONESIA
}

\author{
Yulia Sari ${ }^{1,2,3}$, Sri Haryati ${ }^{1,3}$, Dhani Redhono ${ }^{4}$, Afiono Agung Prasetyo ${ }^{2,3,5^{*}}$ \\ ${ }^{1}$ Department of Parasitology Faculty of Medicine, Sebelas Maret University, \\ JI. Ir. Sutami 36A, Surakarta, Indonesia. \\ ${ }^{2}$ Biomedical Laboratory Faculty of Medicine, Sebelas Maret University, JI. Ir. Sutami 36A, Surakarta, Indonesia. \\ ${ }^{3}$ Center of Biotechnology and Biodiversity Research and Development, Sebelas Maret University, \\ JI. Ir. Sutami 36A, Surakarta, Indonesia. \\ ${ }^{4}$ Department of Internal Medicine, Faculty of Medicine, Sebelas Maret University, \\ JI. Ir. Sutami 36A, Surakarta 57126, Indonesia. \\ ${ }^{5}$ Department of Microbiology Faculty of Medicine, Sebelas Maret University, \\ Jl. Ir. Sutami 36A, Surakarta, Indonesia. \\ * Correspondence author: Afiono Agung Prasetyo, M.D., Ph.D. \\ Department of Microbiology Faculty of Medicine, Sebelas Maret University JI. Ir. Sutami no 36A, Surakarta, \\ Indonesia, Telp.62-271-632489, Fax.62-271-632489, E-mail: afieagp@yahoo.com; afie.agp.la@gmail.com
}

\begin{abstract}
Background: The CCR5 32 polymorphism (a naturally occurring 32-bp deletion in CCR5) influences the ability of HIV-1 to infect the target cells. Homozygosity for CCR $5 \Delta 32$ prevents infection of HIV-1 R5 strain, while the heterozygous is associated with lower plasma viral load and delayed progression to acquired immune deficiency syndrome (AIDS). However, there is no report about the presentation of CCR5 $\Delta 32$ polymorphisms in Indonesian HIV patients. The aim of this study is to detect CCR5 $\Delta 32$ polymorphisms in Indonesian HIV patients, especially in Voluntary Counseling and Testing Moewardi General Hospital Surakarta, Indonesia. In an ongoing molecular epidemiology study of blood borne virus, $154 \mathrm{HIV}$ patients in Moewardi General Hospital Surakarta were used for the study. The blood samples were collected during November December 2011. The blood samples were aliquoted and fractionated. The DNA was extracted from all blood samples, and subjected for the PCR assay to detect the presentation of CCR5 $\Delta 32$ polymorphisms. Internal amplification control was included in all assays. PCR products were analyzed in $3 \%$ agarose. The results showed that CCR5 32 polymorphism was not detected in all blood samples. So it can be concluded that all patients in this study had the CCR5 wild type.
\end{abstract}

Key words: CCR5 32 , HIV, Indonesia.

\section{INTRODUCTION}

Human immunodeficiency virus (HIV) entry into target cells is a multi-step process involving binding of the viral glycoprotein, Env, to its receptor CD4 and a co-receptor of CCR5 or CXCR4. Understanding the means by which HIV enters cells has led to the identification of the CCR $5 \Delta 32$ polymorphism that confers resistance to infection in homozygous individuals, and has also resulted in the development of entry inhibitors-small molecule antagonists that block infection at the entry step (Didigu \& Doms, 2012; Grivel et al., 2011). A natural deletion of 32 bases in CCR5 (CCR5 332 ) gene resulting in truncated protein product (Liu et al., 2012). People homozygous for CCR5Ä32 are naturally resistant to R5 HIV infection and the heterozygous state is associated with up to $2-4$ years delay in disease progression (Gupta \& Padh, 2012). This polymorphism was found in Caucasians and in Chinese state high (Liu et al., 2012) and exists at allele frequencies of typically $10 \%$ in European populations (Hyde et al., 2010). However, to our knowledge, the presence of CCR5 $\Delta 32$ polymorphisms

ISSN 2413-0877 (C) 2015 The Authors.

Published by KnowledgeE Publishing Services This is an open access article under the CC BY-NC-ND license (http://creativecommons.org/licenses/by-nc-nd/4.0)

Selection and Peer-review under responsibility of the 3rd ICBS-2013

Doi http://dx.doi.org/10.18502/kls.v2i1.196 
in Indonesian HIV patients has not been reported. The research aims to detect the CCR5 332 polymorphism in HIV patients in Indonesia, especially in Surakarta, Indonesia.

\section{MATERIALS AND METHODS}

In November - December 2011, HIV patients from Surakarta and its surrounding area of Voluntary Counseling and Testing Moewardi General Hospital Surakarta $(n=154)$ were invited for the ongoing blood borne virus molecular epidemiology study. The ethical issues of this blood sample collection had been approved by the institutional ethical committee review boards of the Faculty of Medicine of Sebelas Maret University and Dr. Moewardi General Hospital, Surakarta, Indonesia. Blood samples collected from the patients were fractionated, aliquoted and kept frozen until further analysis. All the procedures were conducted according to the principles of the Declaration of Helsinki.

The nucleic acid was extracted from all blood samples using High Pure PCR Template Preparation Kits (Roche Diagnostic, Mannheim, Germany) and subjected for the PCR assay to detect the presence of CCR $5 \Delta 32$ polymorphisms using primer set as described previously (Huang et al., 1996), by Amplitaq Gold® 360 DNA Polymerase Kit (Invitrogen, Carlsbad, CA). Human $\beta$-globin was included as internal amplification control in all assays. PCR products were analyzed in $3 \%$ Agarose.

\section{RESULTS AND DISCUSSION}

Using the primer set used the length for CCR 5 wild type is $189 \mathrm{bp}$, but for CCR5 32 is 157 bp (Huang et al., 1996). The human $\beta$-globin PCR product is 100 bp and used as internal amplification control to exclude the false negative results. All genomic DNA were successfully isolated and amplified, showed by the presentation of two expected bands in $3 \%$ agarose after electrophoresis, $100 \mathrm{bp}$ and $189 \mathrm{bp}$ bands, and no sample showed $100 \mathrm{bp}$ and $157 \mathrm{bp}$ bands. Therefore, in this present study, all patients in the study had the CCR5 wild type, and no CCR5 $\triangle 32$ polymorphism was detected. Our results indicated that CCR5 32 polymorphism maybe not exist in Indonesia population, at least in HIV patients involved in the study. However, due to small number of patients enrolled in the study and only HIV patients from Surakarta and its surrounding area were assayed in the present study, a bigger and more adequate sampling method is needed to clarify the presentation of CCR5 332 polymorphism in Indonesian.

\section{ACKNOWLEDGMENT}

This work was supported partially by grants from APBN/DIPA UNS (No. 267a/UN27.16/ PN/2013 and No. 6139a/UN27.16/PN/2013).

\section{REFERENCES}

Didigu, C.A., and R.W. Doms. 2012. Novel approaches to inhibit HIV entry. Viruses, vol. 4:309-324.

Grivel, J.C., R.J. Shattock, and L.B. Margolis. 2011. Selective transmission of R5 HIV-1 variants: Where is the gatekeeper? J Trans/ Med, vol. 9 Suppl 1:S6. 
Gupta, A., and H. Padh. 2012. The global distribution of CCR5 delta 32 polymorphism: role in HIV-1 protection. BMC Infect Dis, vol. 12 (Suppl 1):O16.

Huang, Y., W.A. Paxton, S.M. Wolinsky, A.U. Neumann, L. Zhang, T. He, S. Kang, D. Ceradini, Z. Jin, K. Yazdanbakhsh, K. Kunstman, D. Erickson, E. Dragon, N.R. Landau, J. Phair, D.D. Ho, and R.A. Koup. 1996. The role of a mutant CCR5 allele in HIV-1 transmission and disease progression. Nat Med, vol. 2:1240-1243.

Hyde, C.L., A. Macinnes, F.A. Sanders, J.F. Thompson, R.A. Mazzarella, O. Faergeman, D.F. van Wijk, L. Wood, M. Lira, and S.A. Paciga. 2010. Genetic association of the CCR5 region with lipid levels in at-risk cardiovascular patients. Circ Cardiovasc Genet, vol. 3:162-168.

Liu, S., C. Kong, J. Wu, H. Ying, and H. Zhu. 2012. Effect of CCR5-D32 heterozygosity on HIV-1 susceptibility: A meta-analysis. PLoS ONE, vol. 7: e35020. 